\title{
Changes in the Cerrado vegetation structure: insights from more than three decades of ecological succession
}

\author{
Rogério Victor S. Gonçalves, João Custódio F. Cardoso, Paulo Eugênio Oliveira, and \\ Denis Coelho Oliveira \\ Programa de Pós-Graduação em Ecologia e Conservação de Recursos Naturais, Instituto de Biologia - INBIO, \\ Universidade Federal de Uberlândia - UFU, Uberlândia, Brazil \\ Correspondence: Denis Coelho Oliveira (denisoliveira@ufu.br)
}

Received: 20 October 2020 - Revised: 18 February 2021 - Accepted: 22 February 2021 - Published: 30 March 2021

\begin{abstract}
Changes in the vegetation of Brazilian Cerrado may occur over time. However, long-term dynamics are not fully understood yet, especially woody plant encroachment (WPE). The objective of this study was to examine changes in vegetation structure in a preserved area in Triângulo Mineiro region, within the southern Brazilian Cerrado domain, over 32 years $(1987,2005$, and 2019). We based the study on field and literature surveys, as well as satellite imagery, and hypothesized that, due to the absence of periodic fires or grazing, Cerrado open formations (i.e., grassland or savanna) tend to become denser due to WPE. Shrubby grassland cover assessed in 1987 disappeared in the following periods (from $30.0 \%$ to $0.0 \%$ in 2019) while forest formations increased (from $7.0 \%$ in 1987 to $11.0 \%$ in 2019). Changes between 2005 and 2019 occurred within the stricto sensu cerrado subdivisions, with reduction of sparse cerrado (from $34.2 \%$ to $7.7 \%$ ) and an increase in dense cerrado (from $6.9 \%$ to $39.8 \%$ ). Normalized difference vegetation index (NDVI) applied for similar periods indicates a progressive increase of values over time (from $1986(0.61 \pm 0.10)$ to $2004(0.65 \pm 0.06)$ and 2018 $(0.78 \pm 0.05))$ and corroborates the WPE process. These patterns imply the loss of biodiversity in open plant formation. Another major consequence was the reduction of wetlands and possible impact on water supply. Such patterns are important to support plant management plans for the threatened Cerrado open plant formations.
\end{abstract}

\section{Introduction}

Covering ca. $20 \%$ of the Earth's surface and home to onefifth of the human population, savanna biomes contribute to $30 \%$ of terrestrial net primary production and are considered to be increasingly important to the terrestrial carbon cycle (Stevens et al., 2017). Research in conservation of forest ecosystems and government programs around the world have been increasing in the last decades (Börner et al., 2020) while savanna policies have been focused mainly on fire (Durigan and Ratter, 2016; Schmidt and Eloy, 2020; Van Wilgen et al., 2004). In this sense, there has been much less attention to the conservation of non-forest ecosystems, although the loss of biodiversity seems to be occurring more quickly in these (Overbeck et al., 2015; Veldman et al., 2015). Cerrado is a Brazilian biome dominated by savanna formations located mainly in the central highlands, comprising approximately $2 \times 10^{6} \mathrm{~km}^{2}$ and constituting the second largest biome of the country ( $\sim 22 \%$ of the national territory) (Klink and Machado, 2005; Oliveira et al., 2014). As other tropical savanna regions in the world (Mistry and Beradi, 2014), it includes different plant formations such as forests (i.e., predominance of arboreal species with canopy formation), savannas (i.e., with trees and shrubs sparsely growing over a gramineous stratum), and grasslands/fields (i.e., predominantly ground vegetation and sparse shrubs). Each vegetation type has its dynamics as well as its own associated species pool (Ribeiro and Walter, 2008). This diversity of complex landscapes associated with biodiversity loss makes the Brazilian savanna 1 of the 34 conservation hotspots in the world (Myers et al., 2000; Sawyer, 2019).

Changes in the vegetation structure of tropical savannas commonly occur due to fire, anthropogenic actions, and climate change (Lehmann et al., 2014; Strassburg et al., 2017). Nevertheless, long-term changes in the Cerrado vegetation 
have been observed also due to woody plant encroachment (WPE), an increase in cover, density, and biomass of woody species on open plant formations, usually linked to absent or reduced fires but also due to other possible factors (Stevens et al., 2017). Thus, studies assessing continuous changes in the Cerrado vegetation, especially in areas of diverse plant formations, can improve the understanding of vegetation dynamics and their drivers, providing information to minimize environmental damage and to implement better conservation policies in the Cerrado (Gomes et al., 2018).

In the present study, we aimed to investigate the vegetation dynamics in the largest preserved area in the Triângulo Mineiro. This is a region between the Paranaíba and Grande River, two of the main tributaries of the Paraná-Plata water basin, in the southern Cerrado. This area has been preserved for over 30 years, and here we hypothesize that conservation management, possibly due to reduced fires and grazing, favored WPE and denser plant formations, as observed in other Cerrado areas further south. By using a set of traditional and well-defined Cerrado plant formation categories (Ribeiro and Walter, 2008), we compared differences between our data and those from previous surveys (see Schiavini and Araújo, 1989; Cardoso et al., 2009). Furthermore, we used satellite imagery and NDVI (normalized difference vegetation index) for those sampled years to confirm the amplitude of WPE and landscape changes in the reserve.

\section{Methods}

\subsection{Study area}

The Panga Ecological Station (PES) is a private natural heritage reserve that belongs to the Universidade Federal de Uberlândia (UFU). It was created in 1987 as an area of natural vegetation for research and preservation (Vasconcelos et al., 2014), located in the municipality of Uberlândia, Minas Gerais, Brazil. The area includes the largest fragment (409 ha) of preserved Cerrado in the entire Triângulo Mineiro region. The PES shelters many of the Cerrado savanna plant formations (Schiavini and Araújo, 1989; Cardoso et al., 2009) but also gallery forest areas apparently linked to the Atlantic Forest biome (Oliveira-Filho and Fontes, 2000, Ribeiro and Walter, 2008). The climate in the region is Aw (Alvares et al., 2013), characterized by a rainy and warmer summer season and a dry and cooler winter. The average annual temperature in PES is $22.8^{\circ} \mathrm{C}$, and the average annual rainfall is $1482 \mathrm{~mm}^{3}$ (Cardoso et al., 2009). Although climate parameters fluctuate in the region (e.g., Lima and Campanedo, 2020) there was no verified climate change trend for the region during the study period.

\subsection{Vegetation classification}

We marked 74 control points mainly along paths inside the ecological reserve (Santos and Zuza, 2010) trying to cover the diversity of plant formations. The points were established cumulatively from 2017 to 2019 using a Garmin GPSMAP® 64 , during the rainy seasons. Then, we discriminated the type of plant formation at every point according to Ribeiro and Walter (2008), Schwieder et al. (2016), and Neves et al. (2019). They used percentage of woody cover, height of wood canopy, and seasonal flooding, and even some floristic elements (such as Mauritia flexuosa palm trees) to characterize plant formations in the region. Ribeiro and Walter (2008) also provide a key to identify Cerrado plant formations, and we used their criteria to define the type of plant formation during field work. Throughout the paper, we used "Cerrado" (in capital letters) to refer to the biome and "cerrado" to refer to savanna-like formations within the biome. A base map of the study area was based on Google Earth archives, which stores multispectral images of the SPOT-6 satellite with a spatial resolution of $2.5 \mathrm{~m}$ and a radiometric resolution of 8 bits. We accessed the RGB satellite images from these archives and selected that closest to the period we sampled the vegetation (21 August 2019). We used this image and control points to build a plant formation distribution map. We created the polygons of each vegetation type based on the marked points, image interpretation, and supplementary fieldwork. We initially used an automatic classification supervised by maximum likelihood (MAXVER) available on QGIS 2.18 Semi-Automatic Classification Plugin. MAXVER is a pixel-based classification method that uses the spectral information of each pixel to find homogeneous regions and performs the classification using Bayes' theorem of decision making (Aguilera et al., 2011). Afterwards, we post-processed the classification manually adjusting the polygons and confirming vegetation types which were not clearly differentiated from each other (e.g., evergreen forest from gallery forest, see Table 1) by revising images and conducting supplementary fieldwork. Also, as an accuracy assessment, we sampled at random 100 points inside our study area and checked them by using image interpretation and field experience, if each one of the points was in the right polygon of vegetation type.

We compared the percentages of each plant formation in 2019 with data reported in previous surveys in 1987 (Schiavini and Araújo, 1989) and 2005 (Cardoso et al., 2009). To reduce any methodological bias, we followed similar procedures to those previous studies. Schiavini and Araújo (1989) used image interpretation of aerial photogrammetry with $2.5 \mathrm{~m}$ resolution and collected the data walking all over the station in weekly fieldwork from May 1986 to May 1987, covering all seasons in the PES. Cardoso et al. (2009) used image interpretation from the QuickBird satellite with $2.4 \mathrm{~m}$ resolution and marked 36 control points around the reserve from 2001 to 2005 . In addition to using similar image resolution $(2.5 \mathrm{~m})$, we increased the number of control points in our study in both seasons (74) in an attempt to offset the longer fieldwork time of Cardoso et al. (2009). 
For the analysis, we used traditional Cerrado plant formation classification published both in Portuguese and English language. However, we incorporated cerrado field (campo cerrado in Portuguese) data from 1987 and 2005 into sparse cerrado (sensu Neves et al., 2019), both within stricto sensu cerrado traditional classification (Ribeiro and Walter, 2008), since cerrado field is not usually used. We also reclassified the semideciduous forest, used in the previous surveys, into the evergreen forest, since the traditional classification (sensu Ribeiro and Walter, 2008) does not distinguish between these types of forest.

We classified the PES plant formations into shrubby grassland (campo sujo), palm swamp (vereda), wet grassland (campo úmido), dense cerrado woodland (cerradão), stricto sensu cerrado, evergreen forest (mata sempre verde), gallery forest (mata de galeria), and anthropized area. Stricto sensu cerrado was further divided into sparse cerrado (cerrado ralo), typical cerrado (cerrado típico), and dense cerrado (cerrado denso) (sensu Ribeiro and Walter, 2008). For statistical analysis and discussion, we incorporated vereda palm swamp and wet grasslands as wetlands, since previous surveys (i.e., Schiavini and Araújo, 1989; Cardoso et al., 2009) also used both plant formations aggregated. Based on this classification, we characterized the main features of each plant formation (Table 1).

As the previous approach is based on somewhat subjective vegetation categorization, we also used a normalized difference vegetation index (NDVI) to quantify the dynamics of WPE in the PES. For this analysis we used the Landsat 4/5 TM images for 1986 (24 November) and 2004 (25 November) and Landsat 8 OLI images for 2018 (18 December). These images were chosen based on cloud-free conditions in the closest period from the data collection. We then extracted the NDVI for all pixels of the image for each year. Due to the difference of reflective wavelength between satellites, we performed a correction based on Roy et al. (2016).

\subsection{Statistical analyses}

We investigated if the amount of area occupied by the distinct plant formations differed among the three periods by running a chi-squared test. We computed $p$ values by Monte Carlo simulation (sensu Hope, 1968), with 10000 iterations. After obtaining a statistically significant result, we performed post hoc pairwise tests of independence among the periods using the package rcompanion (Mangiafico, 2019). The Bonferroni correction was applied to avoid type I error. We then performed another chi-squared test (with Monte Carlo simulation; 10000 iterations) to evaluate changes among plant formations of the stricto sensu cerrado complex between 2005 and 2019.

To investigate NDVI differences between years, we fit a generalized linear mixed model (GLMM) with gamma distribution and log link in the lme4 package (Bates et al., 2020). We set NDVI as our response variable and the time periods as our fixed effect while pixel identity was treated as a random effect. We used the likelihood ratio test to attain significance for the fixed effect (i.e., comparing the model with the variable of interest included (full model) against that without it (null model) to assess its $p$ value) (Zuur et al., 2009). We then calculated the proportion of variance explained by both fixed and random effects (conditional $R^{2}$ ) and by the fixed effect alone (marginal $R^{2}$ ) (sensu Nakagawa and Schielzeth, 2013) using the package MuMIn (Bartoń, 2020). To assess differences between the three sampled periods we performed post hoc analysis using the Tukey multiple comparison test in the package emmeans (Lenth et al., 2019). Analyses were conducted in R software version 3.6.0 (R Core Team, 2019).

\section{Results}

The PES had in 2019 many of the plant formations observed in the Cerrado biome (Figs. 1 and 2). Among the 74 surveyed points, 5 were marked in palm swamp, 1 in wet grassland, 10 in dense cerrado woodland, 47 in stricto sensu cerrado, 4 in evergreen forest, and 6 in gallery forest. The shrubby grassland areas were not found in PES anymore. We found almost no open plant formation areas in the PES in 2019. Most areas were similar to dense cerrado or dense cerrado woodland (Fig. 1e-h), while sparse cerrado and other open plant formation (Fig. 1a-d) were harder to find. Altogether, the number of control points marked were 48 for forest formations and only 19 for open plant formations. Even in the wetlands (i.e., vered $a$ and wet grassland areas), where we marked six control points, we found signs of structural changes (Fig. 2a and b) and WPE.

When we compared the recent survey with those previous ones carried out in the PES, we noticed the WPE trends associated with the reduction of open plant formations. There were statistically significant differences among the frequencies of plant formation types $\left(\chi^{2}=292.37\right.$; $\mathrm{df}=$ $10 ; p<0.001$; Fig. 3a), with 1987 differing from both 2005 $(p=0.002)$ and $2019(p=0.002)$, while these latter two did not differ significantly from each other $(p=0.74)$. The shrubby grasslands, for example, which were fairly common in 1987 (ca. 30\%, Fig. 3a), disappeared during the following periods $(0.4 \%$ and $0.0 \%$ in 2005 and 2019 respectively). Similarly, the area occupied by wetlands decreased during the three periods of time: from $9.0 \%$ to $5.8 \%$ and then to $3.7 \%$, respectively. On the other hand, the area occupied by woody plant formations such as stricto sensu cerrado, dense cerrado woodland, and gallery forests increased during the period. Stricto sensu cerrado (49.9\% in 1987) increased in $2005(77.8 \%)$ and $2019(78.8 \%)$ (Fig. 3a). Forest areas represented only $7.0 \%$ in 1987 , increasing to $11.4 \%$ and $11.0 \%$ in 2005 and 2019, respectively. The woody density in stricto sensu cerrado also differed between 2005 and 2019 $\left(\chi^{2}=165.11 ;\right.$ df $=2 ; p<0.001$; Fig. 3b). Sparse cerrado decreased from $34.2 \%$ to $7.7 \%$, and dense cerrado increased 
Table 1. Vegetation classification of PES and their respectively characteristics (according to Ribeiro and Walter, 2008; Neves et al., 2019; Schwieder et al., 2016).

\begin{tabular}{|c|c|c|c|c|}
\hline Vegetation type & Vegetation categories & Plant formation & Tree canopy height (m) & Tree cover $(\%)$ \\
\hline \multirow{2}{*}{ Open plant formations } & Wetlands & $\begin{array}{l}\text { Vereda } \\
\text { Wet grassland }\end{array}$ & $\begin{array}{l}\text { from } 10 \text { to } 15 \mathrm{~m} \\
\text { from } 0 \text { to } 2 \mathrm{~m}\end{array}$ & $\begin{array}{l}\text { from } 5 \% \text { to } 10 \% \\
\text { from } 0 \% \text { to } 5 \%\end{array}$ \\
\hline & Stricto sensu cerrado & $\begin{array}{l}\text { Sparse cerrado } \\
\text { Typical cerrado }\end{array}$ & $\begin{array}{l}\text { from } 2 \text { to } 3 \mathrm{~m} \\
\text { from } 3 \text { to } 6 \mathrm{~m}\end{array}$ & $\begin{array}{l}\text { from } 5 \% \text { to } 20 \% \\
\text { from } 20 \% \text { to } 50 \%\end{array}$ \\
\hline \multirow[b]{2}{*}{ Closed plant formations } & & Dense cerrado & from 5 to $8 \mathrm{~m}$ & from $50 \%$ to $70 \%$ \\
\hline & Forest & $\begin{array}{l}\text { Dense cerrado woodland } \\
\text { Evergreen forest } \\
\text { Gallery forest }\end{array}$ & $\begin{array}{l}\text { from } 8 \text { to } 15 \mathrm{~m} \\
\text { from } 20 \text { to } 30 \mathrm{~m} \\
\text { from } 20 \text { to } 30 \mathrm{~m}\end{array}$ & $\begin{array}{l}\text { from } 50 \% \text { to } 90 \% \\
\text { from } 70 \% \text { to } 95 \% \\
\text { from } 70 \% \text { to } 95 \%\end{array}$ \\
\hline
\end{tabular}

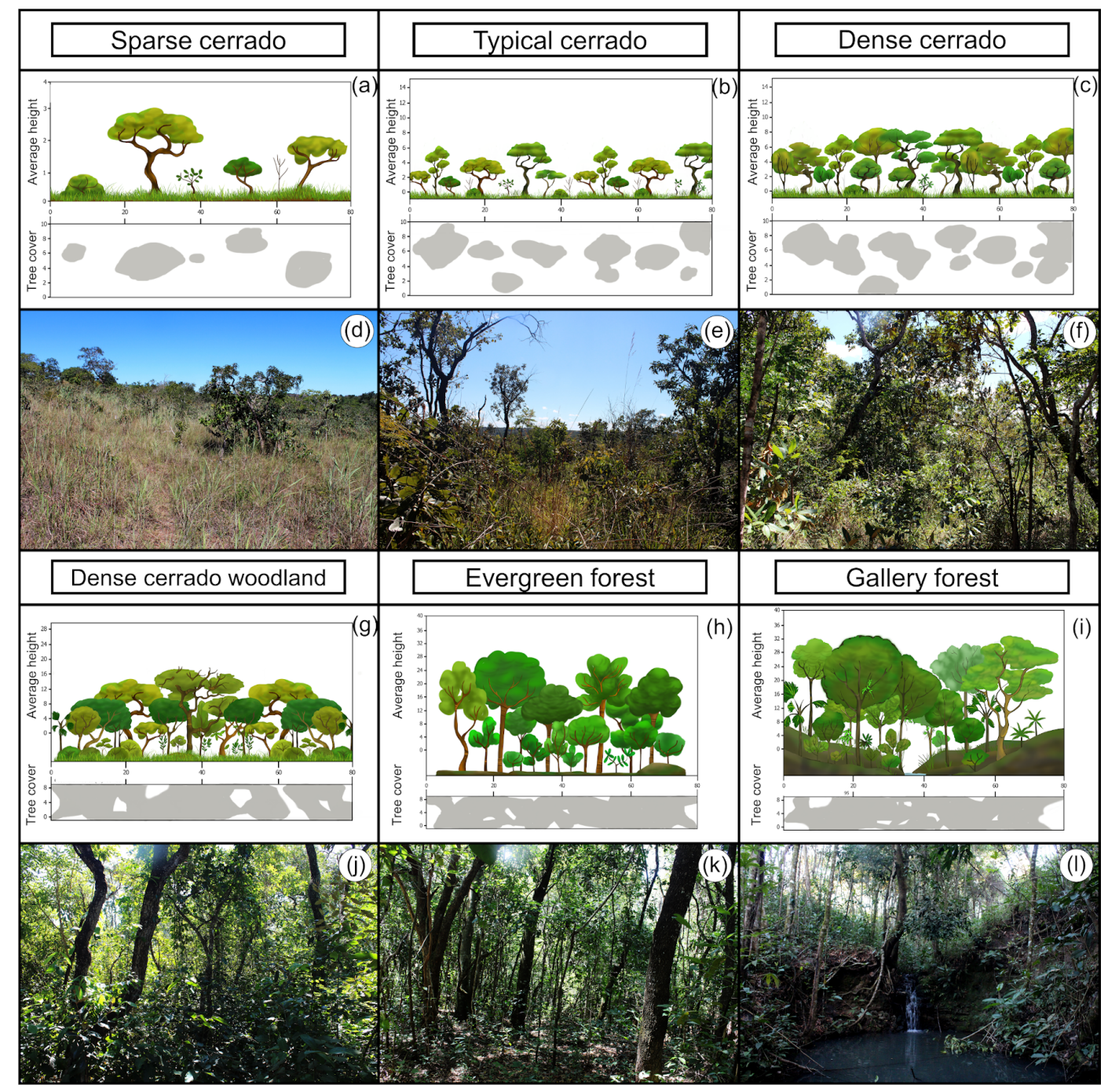

Figure 1. Plant formations of the PES: sparse cerrado (a, d; average height (AH): 2-3 m, tree cover (TC): $5 \%-20 \%$ ); typical cerrado (b, e; AH: 3-6 m, TC: $20 \%-50 \%$ ); dense cerrado (c, f; AH: 5-8 m, TC: 50\%-70\%); dense cerrado woodland (g, h; AH: 8-15 m, TC: 50\%-90\%); evergreen forest (h, k; AH: 20-30 m, TC: 70\%-95\%); gallery forest (i, l; AH: 20-30 m, TC: $70 \%-95 \%$ ). 


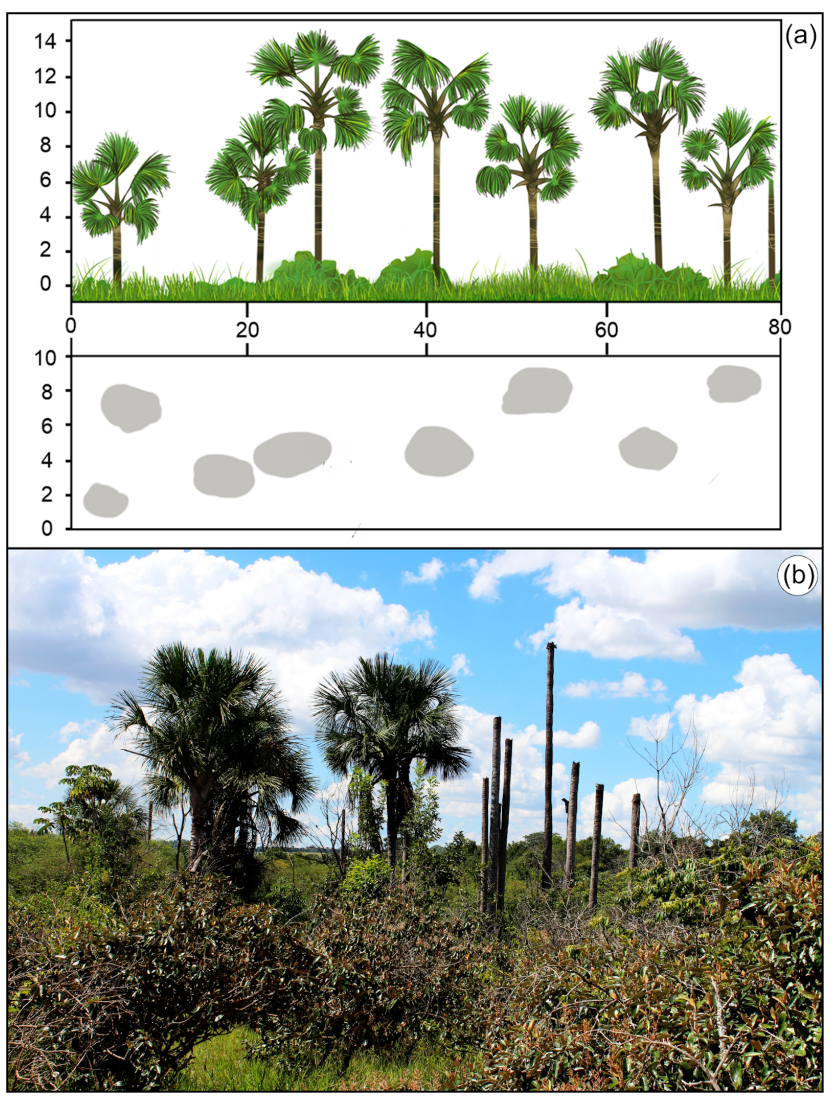

Figure 2. Vereda palm swamp formation (a; average height: 12$15 \mathrm{~m}$, tree cover: 5\%-10\%). Vereda of the PES with the outstanding presence of the buriti palm (Mauritia flexuosa) in permanent wet soil. Dead palm trees and Miconia albicans invasive shrubs (typical of savanna formations) evince structural changes and wood plant encroachment (WPE) in the Vereda surrounding areas (b).

from $6.9 \%$ to $39.8 \%$ (Fig. 3b). The proportions of typical cerrado remained similar between 2005 and 2019 (36.8\% and $31.3 \%$ respectively).

These landscape trends were corroborated by the NDVI value analysis $\left(\chi^{2}=15921 ; \mathrm{df}=2 ; \quad p<0.001\right.$; $R_{\text {conditional }}^{2}=0.73 ; R_{\text {marginal }}^{2}=0.48$; Fig. $\left.3 \mathrm{c}\right)$. NDVI values increased over time from 1987 (mean \pm SD: $0.61 \pm 0.10$ ) to $2005(0.65 \pm 0.06)$ and then to $2019(0.78 \pm 0.05)$ (Figs. 3c and 4$)$, which were all different from each other $(p<0.001)$. The 2019 distribution map of plant formations shows that the reserve is nowadays occupied by stricto sensu cerrado $(78.8 \%)$, followed by forests $(11.0 \%)$, wetlands $(3.7 \%$; vereda: $3.2 \%$, wet grassland: $0.6 \%$ ), dense cerrado woodland $(3.5 \%)$, and then anthropized areas $(0.6 \%)$ (Fig. 5). The accuracy assessment points consistently returned the correct plant formation.
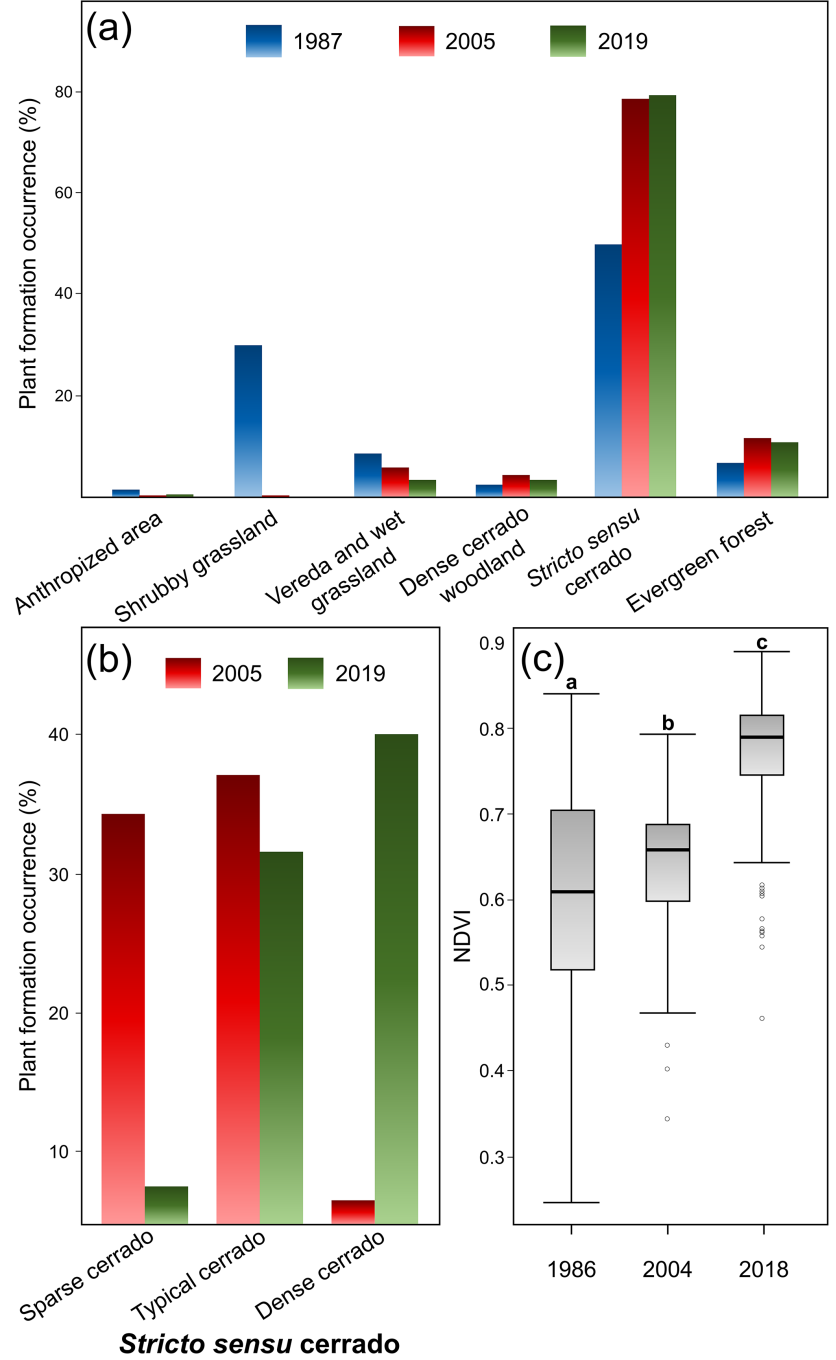

Figure 3. Vegetational changes in the PES over time. (a) Comparison of all plant formations showing their percentage of surface occupied in 1987, 2005 and 2019; (b) the percentage of surface occupation among stricto sensu cerrado categories in 2005 and 2019; and NDVI differences among 1986, 2004 and 2018 surveys. (c) Different letters indicate significant statistical differences at 0.05 level.

\section{Discussion}

Here, we show through plant surveys and landscape analyses that the vegetation of the PES has changed markedly over the last three decades. Open plant formations gave place to denser cerrado and forest formations, a process apparently resulting from WPE, which affected even wetlands. We show important trends in the largest preserved area in the Triângulo Mineiro region, which may be used for decision-making about management of Cerrado environments and as a background for future assessments and hypothesis testing. We discuss below the impact and consequences of these trends for the conservation of Cerrado preservation areas. 


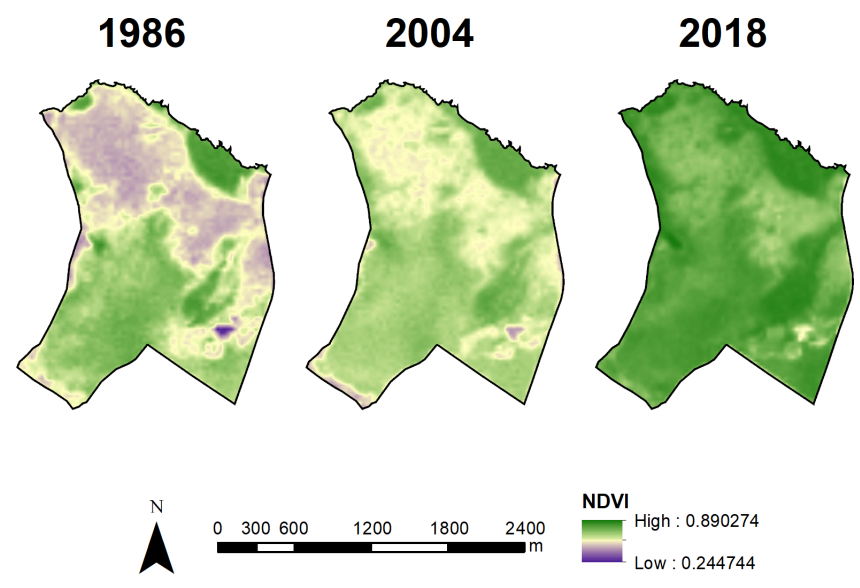

Figure 4. Visual assessment of WPE based on NDVI values of the Panga Ecological Station in 1986, 2004, and 2018.

Long-term studies suggest that the floristic composition of Cerrado changes over time (Libano and Felfili, 2007; Almeida et al., 2014). Although wildfires and deforestation have been seen as the main threats to Cerrado conservation (Klink and Machado, 2005; Strassburg et al., 2017) and Neotropical environments as a whole (Pinto-Ledezma and Rivero-Mamani, 2014; Manchego et al., 2017), in many Cerrado areas, the main changes have been linked to WPE in more open plant formations, which tend to become denser cerrados or even forests (Pinheiro and Durigan, 2009). In the current long-term study, we provide evidence about Cerrado vegetation dynamics in a diverse plant formation area. We demonstrated that during the first interval (18 years), shrubby grassland formations virtually disappeared, giving place to denser plant formations such as sparse and typical cerrados. Also, the area occupied by forest formations increased. During the second interval (14 years), there were no marked changes among grassland, savanna, and forest formations. However, within the stricto sensu cerrado complex, possibly due to WPE, we observed a change from sparse to typical cerrado, and then to denser cerrado. Similar trends have been observed in other Cerrado areas, especially further south (Libano and Felfili, 2007; Pinheiro and Duringan, 2009), and have been linked to fire protection policies (Duringan and Ratter, 2016). The structural changes result from an increase in woody species dominance, biomass, and shading, possibly excluding plant and animal species adapted to more sparse plant formations (Moreira, 2000; Miranda et al., 2002; Gomes et al., 2018).

Since the structural changes may be viewed as based on a somewhat subjective vegetation categorization, we also used a normalized difference vegetation index (NDVI) to quantify WPE dynamics in PES. NDVI is the closest assessment to estimate vegetation cover and a proxy of biomass increment. The increment of NDVI values over time corroborated WPE trends and biomass accumulation in PES reserve, which can be associated with loss of open vegetation types, such as shrubby grassland, wetlands, and sparse cerrado. This phenomenon was already investigated as a threat to savanna biodiversity, leading to the establishment of invasive plants (Alofs and Fowler, 2013; Ratajczak et al., 2012). For instance, in PES, this can be shown by the increasing dominance of Miconia albicans, an apomictic and putatively invasive species (Dias et al., 2018), in typical and dense cerrado formations.

WPE is widespread in savanna biomes across the world and is not related simply to annual precipitation, but rather to the continent where they are located (Stevens et al., 2017). The geographical separation may cause differences in functional traits of woody species, such as the ability to fix $\mathrm{N}$, which affects WPE, but fire has been seen as a main driver to the process (Durigan and Ratter, 2016; Stevens et al., 2017), and grazing exclusion is also often associated with WPE (Stevens et al., 2017). For instance, on average, the WPE rate of Brazilian savannas is respectively 3 and 7 times greater than that of African and Australian savannas (Stevens et al., 2017), a fact that can be explained, to a certain extent, by the Brazilian conservation policies, commonly suppressing fire and cattle-grazing (Klink and Machado, 2005; Duringan and Ratter, 2016). Over time, dead plant biomass, especially fine fuel, is accumulated in the soil and periodic fires keep the carbon cycle (Bowman et al., 2009; Gomes et al., 2020). In the Cerrado, fire periodicity is estimated to be from 3 to 6 years (Pereira et al., 2014). When periodic fires are suppressed and grazers are removed, commonly there is an increase of biomass that may over-accumulate, and the exclusion of grazers makes removal of these fine fuels complicated, resulting in uncontrollable fires which lead to negative impacts on biodiversity (Silveira et al., 1999; Miranda et al., 2002). Post-fire regeneration of dense vegetation without periodic fires for a long time may cause rapid regeneration into even denser formations, without taking the community to previous successional stages (Briske, 2017). This occurs because periods much longer than the usual cycle of fire lead to the loss of herb and grass propagules in the soil accompanied by the dominance of woody species, which may shade and outcompete herbaceous elements. Denser habitats have different profiles of light incidence, temperature, humidity, and soil properties, which exclude many plant and animal species from the community (Nilsson et al., 1997; Vale et al., 2013; Saldan and Fahrig, 2017; Raymundo et al., 2019). In this sense, the WPE process causes loss of diversity associated with open plant formations (e.g., grassland and sparse cerrado), since there are endemic species of such environments that do not adapt to denser shaded habitats (e.g., forests and dense cerrados; Moreira, 2000). Although we cannot link directly to fire suppression or grazing exclusion, we showed that WPE is widespread across the PES Reserve and has been occurring rapidly after protection, and exclusion of fire and grazing, as in other areas of savanna (Mitchard et al., 2009; Stevens et al., 2017). 


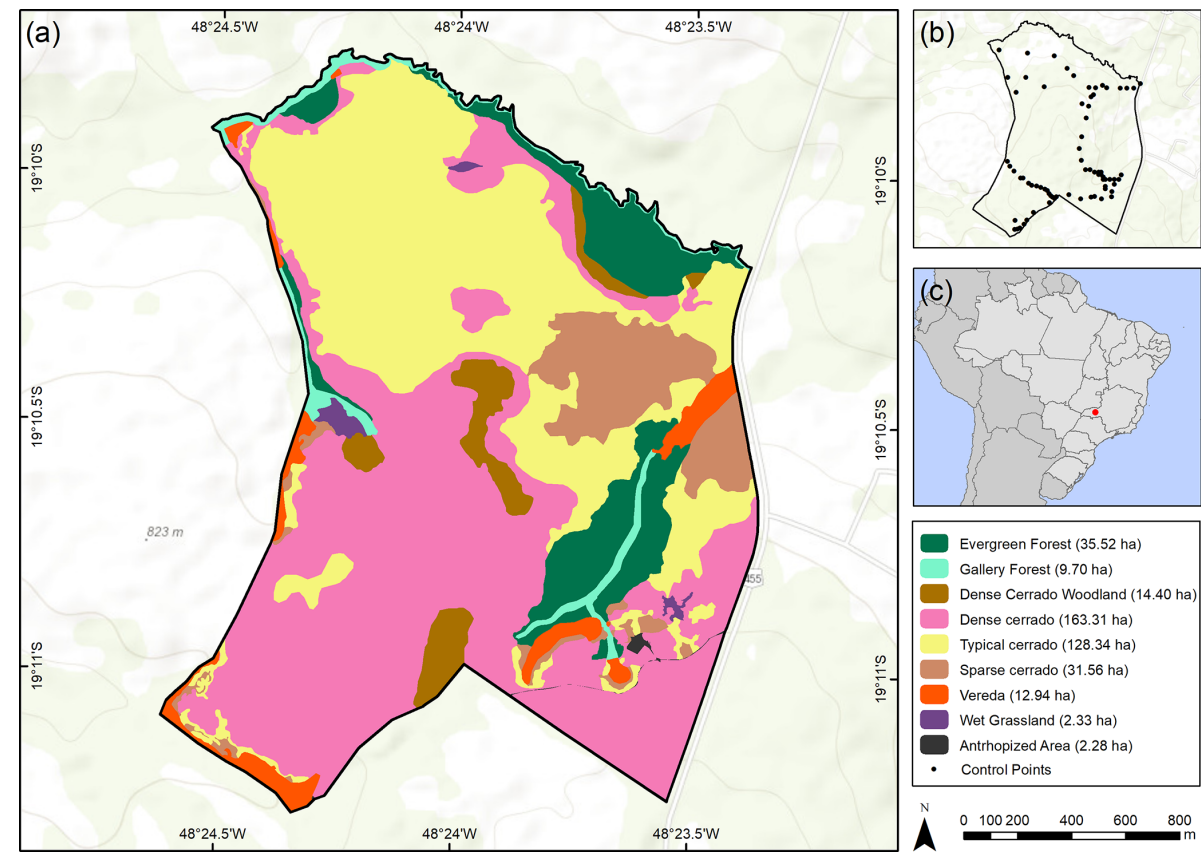

Figure 5. Occurrence of plant formation types in the PES. (a) Map of plant formations based on photo interpretation and fieldwork; (b) control points marked during fieldwork; and (c) location of the studied area in Brazil.

Finally, one of the major consequences of WPE in the studied area is related to the disappearance of the wetlands. These are special environments in which the water table emerges, feeding subsequently streams and rivers (Boaventura, 2007). These wetlands in central Brazil comprise a unique pool of species, many of them endemic (Araújo et al., 2002), and serve as ecological corridors for fauna and flora (Boaventura, 2007). The increasing depth of the water table (Meirelles et al., 2004) causes the invasion of woody species in this formation, which changes soil and species composition (Cardoso et al., 2009; Deus and Oliveira, 2016; Silva et al., 2016), affects water availability (Honda and Durigan, 2016), and harms conservation of surrounding natural areas and even the local agriculture-based economy. There is evidence that denser cerrado areas may use water more intensively and affect soil water content (Duringan and Ratter, 2016; Oliveira et al., 2017). A progressive reduction of wetlands over the years may also be caused by changes in periodic fire regimes, since they are important to the maintenance of wetland vegetation structure (Araújo et al., 2013). Wetland reduction may be also related to changes caused by anthropogenic impacts, such as deforestation and fertilizer application, in the surrounding matrix. These activities reduce water permeation in the soil and may decrease water table levels, leading to changes in neighbor wetland communities (Van Auken, 2009; Silva et al., 2016). The shrinkage of wetlands highlights the importance of management plans for these ecologically and economically important environments.

\section{Conclusions}

Long-term studies on the dynamics of tropical savannas may provide insights on conservation strategies. Here we showed that during 30 years the PES lost most of its open plant formations and wetlands. This corroborates a trend of WPE, as already described for other Cerrado areas elsewhere in Brazil and for savannas in other continents. The loss of open plant formations may threat herbaceous plants and other organisms adapted to open environments. Altogether, our results reinforce that a revision of conservation policies based on fire and grazing suppression in the Cerrado biome is required. This may help decision-making about how to manage such environments with controlled periodic fires as well as the preservation of surrounding areas.

Code availability. There is no underlying code to be made available. All analyses and algorithms used were referred to in the papers.

Data availability. All data used were either presented or referred to in the text and are publicly available.

Author contributions. RVSG and JCFC collected and analyzed the field data and image processing and wrote the first draft of the manuscript. PEO and DCO coordinated the project and contributed 
to the following versions of the paper and provided the expertise on plant formations and historic changes in the area.

Competing interests. The authors declare that they have no conflict of interest.

Acknowledgements. We are grateful to PELD/CAPES/CNPq for financial support. RVSG thanks Coordenação de Aperfeiçoamento de Pessoal de Nível Superior (CAPES) for a MSc grant (CAPES Finance code 88887.463631/2019-00). DCO is grateful for the fellowship provided by Conselho Nacional de Desenvolvimento Científico e Tecnológico (CNPq). PEO is also grateful to CNPq for his research grant and financial support. The authors are grateful to Guilherme Arantes for field support. We dedicate this paper in memory of Serginho (Sérgio Gonçalves de Oliveira), who was passionate about the PES and greatly assisted us during several research activities in the area.

Financial support. This research has been supported by PELD/CAPES/CNPq (grant no. 441225/2016-0), CNPq (grant nos. 431873/2018-6 and 301246/2016-5), and FAPEMIG (grant no. RED-00253-16).

Review statement. This paper was edited by Sonja Knapp and reviewed by D. I. Kelley and Rose Waswa.

\section{References}

Aguilera, P. A., Fernández, A., Fernández, R., Rumí, R., and Salmerón, A.: Bayesian networks in environmental modelling, Environ. Model. Softw., 26, 1376-1388, https://doi.org/10.1016/j.envsoft.2011.06.004, 2011.

Almeida, R. F., Fagg, C. W., De Oliveira, M. C., Beatriz, C., Munhoz, R., Lima, A. S. De, Soares, L., and Oliveira, B. De: Mudanças florísticas e estruturais no cerrado sensu stricto ao longo de 27 anos (1985-2012) na Fazenda Água Limpa, Brasília, DF, Rodriguésia, 65, 1-19, https://doi.org/10.1590/S2175-78602014000100001, 2014.

Alofs, K. M. and Fowler, N. L.: Loss of native herbaceous species due to woody plant encroachment facilitates the establishment of an invasive grass, Ecology, 94, 751-760, https://doi.org/10.1890/12-0732.1, 2013.

Alvares, C. A., Stape, J. L., Sentelhas, P. C., De Moraes Gonçalves, J. L., and Sparovek, G.: Köppen's climate classification map for Brazil, Meteorol. Z., 22, 711-728, https://doi.org/10.1127/09412948/2013/0507, 2013.

Araújo, G. M., Barbosa, A. A. A., Arantes, A. A., and Amaral, A. F.: Composição florística de veredas no Município de Uberlândia, MG, Rev. Bras. Botânica, 25, 475-493, https://doi.org/10.1590/s0100-84042002012000012, 2002.

Araújo, G. M., Amaral, A. F., Bruna, E. M., and Vasconcelos, H. L.: Fire drives the reproductive responses of herbaceous plants in a Neotropical swamp, Plant Ecol., 214, 1479-1484, https://doi.org/10.1007/s11258-013-0268-9, 2013.
Van Auken, O. W.: Causes and consequences of woody plant encroachment into western North American grasslands, J. Environ. Manag., 90, 2931-2942, https://doi.org/10.1016/j.jenvman.2009.04.023, 2009.

Bartoń, K.: Package "MuMIn", v. 1.43.17, CRAN, available at: https://cran.r-project.org/web/packages/MuMIn/index.html (last access: 26 March 2021), 2020.

Bates, D., Maechler, M., Bolker, B., Walker, S., and Team, R. C.: lme4: Linear mixed-effects models using Eigen and S4, R Package, online, available at: https://cran.r-project.org/package=lme4 (24 March 2021), 2020.

Boaventura, R. S.: Vereda: Berço das Águas, Embrapa, Ecodinâmica, Belo Horizonte, 2007.

Börner, J., Schulz, D., Wunder, S., and Pfaff, A.: The effectiveness of forest conservation policies and programs, Annu. Rev. Resour. Econ., 12, 45-64, https://doi.org/10.1146/annurevresource-110119-025703, 2020.

Bowman, D. M. J. S., Balch, J. K., Artaxo, P., Bond, W. J., Carlson, J. M., Cochrane, M. A., D’Antonio, C. M., DeFries, R. S., Doyle, J. C., Harrison, S. P., Johnston, F. H., Keeley, J. E., Krawchuk, M. A., Kull, C. A., Marston, J. B., Moritz, M. A., Prentice, I. C., Roos, C. I., Scott, A. C., Swetnam, T. W., Van Der Werf, G. R., and Pyne, S. J.: Fire in the earth system, Science, 324, 481-484, https://doi.org/10.1126/science.1163886, 2009.

Briske, D. D. (ed.): Rangeland Systems Processes, Management and Challenges, 1st ed., Springer International Publishing, Berlin, 2017.

Cardoso, E., Moreno, M. I. C., Bruna, E. M., and Vasconcelos, H. L.: Mudanças fitofisionômicas no cerrado: 18 anos de sucessão ecológica na Estação Ecológica do Panga, Uberlândia - MG, Caminhos Geogr., 10, 254-268, online, available at: http://www.seer.ufu.br/index.php/caminhosdegeografia/ article/view/15980/9012 (last access: 24 March 2021), 2009.

Deus, F. F. and Oliveira, P. E.: Changes in floristic composition and pollination systems in a "Cerrado" community after 20 years of fire suppression, Rev. Bras. Bot., 39, 1051-1063, https://doi.org/10.1007/s40415-016-0304-9, 2016.

Dias, A. C. C., Serra, A. C., Sampaio, D. S., Borba, E. L., Bonetti, A. M., and Oliveira, P. E.: Unexpectedly high genetic diversity and divergence among populations of the apomictic Neotropical tree Miconia albicans, Plant Biol., 20, 244-251, https://doi.org/10.1111/plb.12654, 2018.

Durigan, G. and Ratter, J. A.: The need for a consistent fire policy for Cerrado conservation, J. Appl. Ecol., 53, 11-15, https://doi.org/10.1111/1365-2664.12559, 2016.

Gomes, L., Miranda, H. S., and Bustamante, M. M. C.: How can we advance the knowledge on the behavior and effects of fire in the Cerrado biome?, For. Ecol. Manage., 417, 281-290, https://doi.org/10.1016/j.foreco.2018.02.032, 2018.

Gomes, L., Miranda, H. S., Silvério, D. V., and Bustamante, M. M.: Effects and behaviour of experimental fires in grasslands, savannas, and forests of the Brazilian Cerrado, Forest Ecol. Manag., 458, 117804, https://doi.org/10.1016/j.foreco.2019.117804, 2020.

Honda, E. A. and Durigan, G.: Woody encroachment and its consequences on hydrological processes in the savannah, Philos. T. Roy. Soc. B, 371, 20150313, https://doi.org/10.1098/rstb.2015.0313, 2016. 
Hope, A. C. A.: A Simplified Monte Carlo Significance Test Procedure, J. R. Stat. Soc. Ser. B, 30, 582-598, https://doi.org/10.1111/j.2517-6161.1968.tb00759.x, 1968.

Klink, C. A. and Machado, R. B.: Conservation of the Brazilian Cerrado, Conserv. Biol., 19, 707-713, https://doi.org/10.1111/j.1523-1739.2005.00702.x, 2005.

Lehmann, C. E. R., Anderson, T. M., Sankaran, M., Higgins, S. I., Archibald, S., Hoffmann, W. A., Hanan, N. P., Williams, R. J., Fensham, R. J., Felfili, J., Hutley, L. B., Ratnam, J., San Jose, J., Montes, R., Franklin, D., Russell-Smith, J., Ryan, C. M., Durigan, G., Hiernaux, P., Haidar, R., Bowman, D. M. J. S., and Bond, W. J.: Savanna vegetation-fire-climate relationships differ among continents, Science, 343, 548-552, https://doi.org/10.1126/science.1247355, 2014.

Lenth, R. V., Buerkner, P., Herve, M., Love, J., Riebl, H., and Singmann, H.: Estimated Marginal Means, aka Least-Squares Means, R package version 1.3.2, available at: https://www. rdocumentation.org/packages/emmeans/versions/1.5.3 (last access: 24 March 2021), 2019.

Libano, A. M. and Felfili, J. M.: Mudanças temporais na composição florística e na diversidade de um cerrado sensu stricto do Brasil Central em um período de 18 anos (1985-2003), Acta Bot. Brasilica, 20, 927-936, https://doi.org/10.1590/s010233062006000400016, 2007.

Lima, M. de P. and Carpenedo, C. B.: Eventos extremos secos em Uberlândia-MG e circulação atmosférica associada, Rev. Bras. Climatol., 27, 158-180, available at: https: //revistas.ufpr.br/revistaabclima/article/view/70256/41150 (last access: 24 March 2021), 2020.

Manchego, C. E., Hildebrandt, P., Cueva, J., Espinosa, C. I., Stimm, B., and Günter, S.: Climate change versus deforestation: Implications for tree species distribution in the dry forests of southern Ecuador, PLoS One, 12, 1-19, https://doi.org/10.1371/journal.pone.0190092, 2017.

Mangiafico, S.: Functions to Support Extension Education Program Evaluation, online, available at: https://cran.r-project.org/web/ packages/rcompanion/index.html (last access: 26 March 2021), 2019.

Meirelles, M. L., Guimarães, A. J. M., Oliveira, R. C., Araújo, G. M., and Ribeiro, J. F.: Impactos sobre o estrato herbáceo de áreas úmidas do Cerrado, in Cerrado: ecologia e caracterização, edited by: Aguiar, L. M. S. and Camargo, A. J. A., 41-68, EMBRAPA, Brasília, 2004.

Miranda, H. S., Bustamante, M. M., and Miranda, A. C.: The fire factor, in: The cerrados of Brazil: ecology and natural history of a neotropical savanna, edited by: Oliveira, P. S. and Marquis, R., Columbia University Press, New York, 51-68, 2002.

Mistry, J. and Beradi, A.: World savannas: ecology and human use, 1st ed., Routledge, Abingdon, England, 2014.

Mitchard, E. T. A., Saatchi, S. S., Gerard, F. F., Lewis, S. L., and Meir, P.: Measuring woody encroachment along a forestsavanna boundary in Central Africa, Earth Interact., 13, 1-29, https://doi.org/10.1175/2009EI278.1, 2009.

Moreira, A. G.: Effects of fire protection on savanna structure in central Brazil, J. Biogeogr., 27, 1021-1029, https://doi.org/10.1046/j.1365-2699.2000.00422.x, 2000.

Myers, N., Mittermeier, R. A., Mittermeier, C. G., Fonseca, G. A. B. $\mathrm{da}$, and Kent, J.: Biodiversity hotspots for conservation priorities, Nature, 403, 853, https://doi.org/10.1038/35002501, 2000.
Nakagawa, S. and Schielzeth, H.: A general and simple method for obtaining R2 from generalized linear mixed-effects models, Methods Ecol. Evol., 4, 133-142, https://doi.org/10.1111/j.2041210x.2012.00261.x, 2013.

Neves, A. K., Korting, T. S., Neto, C. D. G., Soares, A. R., and Fonseca, L. M. G.: Hierarchical classification of Brazilian savanna physiognomies using very high spatial resolution image, superpixel and geobia, IGARSS 2019-2019, IEEE Int. Geosci. Remote Sens. Symp., 2019, 3716-3719, https://doi.org/10.1109/IGARSS.2019.8898649, 2019.

Nilsson, C., Jansson, R., and Zinko, U.: Long-Term Responses of River-Margin Vegetation to Water-Level Regulation, Science, 276, 798-800, https://doi.org/10.1126/science.276.5313.798, 1997.

Oliveira-Filho, A. T. and Fontes, M. A. L.: Patterns of floristic differentiation among atlantic forests in southeastern Brazil and the influence of climate, Biotropica, 32, 793-810, https://doi.org/10.1111/j.1744-7429.2000.tb00619.x, 2000.

Oliveira, P. T. S., Nearing, M. A., Moran, M. S., Goodrich, D. C., Wendland, E., and Gupta, H. V.: Trends in water balance components across the Brazilian Cerrado, Water Resources Researcher, 50, 7100-7114, https://doi.org/10.1002/2013WR014333, 2014.

Oliveira, P. T. S., Leite, M. B., Mattos, T., Nearing, M. A., Scott, R. L., de Oliveira Xavier, R., da Silva Matos, D. M., and Wendland, E.: Groundwater recharge decrease with increased vegetation density in the Brazilian cerrado, Ecohydrology, 10, 1-8, https://doi.org/10.1002/eco.1759, 2017.

Overbeck, G. E., Vélez-Martin, E., Scarano, F. R., Lewinsohn, T. M., Fonseca, C. R., Meyer, S. T., Müller, S. C., Ceotto, P., Dadalt, L., Durigan, G., Ganade, G., Gossner, M. M., Guadagnin, D. L., Lorenzen, K., Jacobi, C. M., Weisser, W. W., and Pillar, V. D.: Conservation in Brazil needs to include non-forest ecosystems, Divers. Distrib., 21, 1455-1460, https://doi.org/10.1111/ddi.12380, 2015.

Pereira, A. C., Oliveira, S. L. J., Pereira, J. M. C., and Turkman, M. A. A.: Modelling fire frequency in a Cerrado savanna protected area, PLoS One, 9, e102380, https://doi.org/10.1371/journal.pone.0102380, 2014.

Pinheiro, E. and Durigan, G.: Dinâmica espaço-temporal (19622006) das fitofisionomias em unidade de conservação do Cerrado no Sudeste do Brasil, Rev. Bras. Bot, 32, 441-454, https://doi.org/10.1590/S0100-84042009000300005, 2009.

Pinto-Ledezma, J. N. and Rivero Mamani, M. L.: Temporal patterns of deforestation and fragmentation in lowland Bolivia: implications for climate change, Clim. Change, 127, 43-54, https://doi.org/10.1007/s10584-013-0817-1, 2014.

$\mathrm{R}$ Core Team: R: A language and environment for statistical computing, online, available at: http://finzi.psych.upenn.edu/R/ library/dplR/doc/intro-dplR.pdf (last access: 26 March 2021), 2019.

Ratajczak, Z., Nippert, J. B., and Collins, S. L.: Woody encroachment decreases diversity across North American grasslands and savannas, Ecology, 93, 697-703, https://doi.org/10.1890/101922.1, 2012.

Raymundo, D., Prado-Junior, J., Alvim Carvalho, F., Santiago do Vale, V., Oliveira, P. E., and van der Sande, M. T.: Shifting species and functional diversity due to abrupt changes in water availability in tropical dry forests, J. Ecol., 107, 253-264, https://doi.org/10.1111/1365-2745.13031, 2019. 
Ribeiro, J. F. and Walter, B. M. T.: As prinfipais fitofisiononomias do bioma Cerrado, in Cerrado: ambiente e flora, edited by: Sano, S. M. and de Almeida, S. P., Embrapa Cerrados, Planaltina, online, available at: http://ainfo.cnptia.embrapa.br/digital/bitstream/item/136069/

1/fitofisionomias-do-Bioma-Cerrado-2.pdf (last access: 26 March 2021), 2008.

Roy, D. P., Kovalskyy, V., Zhang, H. K., Vermote, E. F., Yan, L., Kumar, S. S., and Egorov, A.: Characterization of Landsat-7 to Landsat- 8 reflective wavelength and normalized difference vegetation index continuity, Remote Sens. Environ., 185, 57-70, https://doi.org/10.1016/j.rse.2015.12.024, 2016.

Saldan, R. A. and Fahrig, L.: Does forest fragmentation cause an increase in forest temperature?, Ecol. Res., 32, 81-88, https://doi.org/10.1007/s11284-016-1411-6, 2017.

Santos, D. G. and Zuza, M. L. R.: Avaliação qualitativa das trilhas da RPPN Panga - Uberlândia - MG, Caminhos Geogr., 11, 22-33, available at: http://www.seer.ufu.br/index.php/ caminhosdegeografia/article/view/16214, 2010.

Sawyer, D.: Ecosystem Profile Cerrado Biodiversity Hotspot, Crit. Ecossystem Partn. Fund, 61, available at: http://cepfcerrado.iieb.org.br/wp-content/uploads/2019/12/

FINALVERSIONWEB_Full_report_25MAIO2019.pdf (last access: 23 March 2021), 2019.

Schiavini, I. and Araújo, G. M.: Considerações sobre a vegetação da Reserva Ecológica do Panga (Uberlândia), Soc. Nat. Resour., 1, 61-66, 1989.

Schmidt, I. B. and Eloy, L.: Fire regime in the Brazilian Savanna: Recent changes, policy and management, Flora, 268, 151613, https://doi.org/10.1016/j.flora.2020.151613, 2020.

Schwieder, M., Leitão, P. J., da Cunha Bustamante, M. M., Ferreira, L. G., Rabe, A., and Hostert, P.: Mapping Brazilian savanna vegetation gradients with Landsat time series, Int. J. Appl. Earth Obs. Geoinf., 52, 361-370, https://doi.org/10.1016/j.jag.2016.06.019, 2016.

Silva, B. da, Arieira, F. H., Parolin, J., Cunha, P. N. da, Junk, C., and Johannes, W.: Shrub encroachment influences herbaceous communities in flooded grasslands of a neotropical savanna wetland, Appl. Veg. Sci., 19, 391-400, https://doi.org/10.1111/avsc.12230, 2016.
Silveira, L., Henrique, F., Rodrigues, G., de Almeida Jácomo, A. T., and Filho, J. A. F. D.: Impact of wildfires on the megafauna of Emas National Park, central Brazil, Oryx, 33, 108, https://doi.org/10.1017/s0030605300030362, 1999.

Stevens, N., Lehmann, C. E. R., Murphy, B. P., and Durigan, G.: Savanna woody encroachment is widespread across three continents, Glob. Change Biol., 23, 235-244, https://doi.org/10.1111/gcb.13409, 2017.

Strassburg, B. B. N., Brooks, T., Feltran-Barbieri, R., Iribarrem, A., Crouzeilles, R., Loyola, R., Latawiec, A. E., Oliveira Filho, F. J. B., De Scaramuzza, C. A. M., Scarano, F. R., SoaresFilho, B., and Balmford, A.: Moment of truth for the Cerrado hotspot, Nat. Ecol. Evol., 1, 1-3, https://doi.org/10.1038/s41559017-0099, 2017.

Vale, V. S. do, Schiavini, I., Araújo, G. M., Gusson, A. E., Lopes, S. de F., Oliveira, A. P. de, Júnior, J. A. do P., de Arantes, C. S., and Neto, O. C. D.: Fast changes in seasonal forest communities due to soil moisture increase after damming, Int. J. Trop. Biol. Conserv., 61, 1901-1917, 2013.

Vasconcelos, H. L., Araújo, G. M., and Gonzaga, E. A. R.: Plano de manejo - RPPN Reseva Ecológica do Panga, Inst. Bras. do Meio Ambient. e dos Recur. Nat. Renov., Uberlândia, 2014.

Veldman, J. W., Overbeck, G. E., Negreiros, D., Mahy, G., Le Stradic, S., Fernandes, G. W., Durigan, G., Buisson, E., Putz, F. E., and Bond, W. J.: Where Tree Planting and Forest Expansion are Bad for Biodiversity and Ecosystem Services, Bioscience, 65, 1011-1018, https://doi.org/10.1093/biosci/biv118, 2015.

Van Wilgen, B. w., Govender, N., Biggs, H. c., Ntsala, D., and Funda, X. n.: Response of Savanna Fire Regimes to Changing Fire-Management Policies in a Large African National Park, Conserv. Biol., 18, 1533-1540, https://doi.org/10.1111/j.15231739.2004.00362.x, 2004.

Zuur, A. F., Ieno, E. N., Walker, N. J., Saveliev, A. A., and Smith, G. M.: Zero-Truncated and Zero-Inflated Models for Count Data, in Mixed Effects Models and Extensions in Ecology with R, vol. 1, edited by: Zuur, A. F., Ieno, E. N., Walker, N. J., Saveliev, A. A., and Smith, G. M., 531-561, Springer US, New York, 2009. 